\title{
PENGARUH TERAPI SLOW STROKE BACK MASSAGE (SSBM) TERHADAP PERUBAHAN TEKANAN DARAH PADA PASIEN STROKE NON HEMORAGIK DI RUANG MELATI 4 RSUP. DR. SOERADJI TIRTONEGORO KLATEN
}

\author{
Sekar Pinasthika ${ }^{1}$ \\ ${ }^{1}$ Kementerian Kesehatan Politeknik Kesehatan Surakarta Jurusan Keperawatan \\ Diterima : 13 Mei 2018, Disetujui : 21 Mei 2018
}

\begin{abstract}
Background. Almost 50\% of stroke caused by blood pressure increase. Management Non Haemorrhagic Stroke patients in non critical phase to lowering blood pressure can be done with non-pharmacologic therapy and pharmacologic therapy. Slow Stroke Back Massage is one of the non-pharmacological therapy relaxation which can lower blood pressure. The purpose of this research is to 1) Determine the effect of slow stroke back massage therapy to changes in blood pressure in patients with non-hemorrhagic stroke. 2) To describe characteristics of patients with non-hemorrhagic stroke 3) Determine the change in blood pressure in patients with non-hemorrhagic stroke before and after slow-stroke back massage therapy. Methods. Type of this research is quasi experiment with the design of One Group Pretest-Posttest Design. The Results. The result of this research is there influence of Slow Stroke Back Massage therapy to changes in blood pressure in patients with non-hemorrhagic stroke in Melati 4. This is evidenced by the results of the Wilcoxon test analysis where the systolic blood pressure before and after therapy SSBM $\rho=0.000$ and a significance value of diastolic blood pressure before and after therapy $\operatorname{SSBM} \rho=0.003$. Because the value of $\rho<0.05$, then Ho is rejected and Ha accepted, Conclusion. There is the influence of Slow Stroke Back Massage therapy to changes in blood pressure in patients with non-hemorrhagic stroke in Melati 4 Dr. Soeradji Tirtonegoro, Klaten General Hospital.
\end{abstract}

Keywords: Slow Stroke Back Massage Therapy, Blood Pressure, Non Haemorrhagic Stroke

\section{PENDAHULUAN}

Di antara penyakit-penyakit neurologi yang terjadi pada orang dewasa, stroke menduduki rangking pertama baik pada frekuensinya maupun pada pentingnya (emergensi) penyakit tersebut. Lebih dari $50 \%$ kasus stroke merupakan penyebab dirawatnya penderita di bangsal neurologi (Victor \& Ropper, 2001).

Di Amerika Serikat Stroke menduduki peringkat ke-3 penyebab kematian setelah penyakit jantung dan kanker. Setiap tahunnya 500.000 orang Amerika terserang stroke di antaranya 400.000 orang terkena stroke iskemik dan 100.000 orang menderita stroke hemoragik (termasuk perdarahan intraserebral dan subarakhnoid) dengan 175.000 orang mengalami kematian (Victor \& Ropper, 2001).

Stroke merupakan penyakit pembuluh darah otak dengan kejadian, kecacatan, dan kematian yang cukup 
tinggi. Jumlah pasien penyakit stroke merupakan jumlah pasien terbanyak pada rawat jalan (jumlah kasus baru) maupun rawat inap (jumlah pasien keluar).

Jenis stroke yang paling banyak ditemukan adalah stroke iskemik dengan angka kejadian $88 \%$, sedangkan stroke hemoragik sekitar $12 \%$. Walaupun angka kejadian stroke iskemik lebih tinggi, tetapi angka harapan hidup pasien stroke iskemik lebih baik daripada stroke hemoragik, namun demikian kecacatan stroke iskemik lebih berat karena terjadi kerusakan neuron-neuron yang terkena iskemik (Dipiro dkk., 2011).

$$
\text { Hasil Riskesda }
$$

menunjukkan prevalensi stroke di Indonesia ditemukan sebesar 7,0 per 1000 penduduk, dan yang telah terdiagnosis oleh tenaga kesehatan adalah 12,1 per 1000 penduduk. Hal ini menunjukkan sekitar 57,9\% kasus stroke di masyarakat telah didiagnosis oleh tenaga kesehatan. Angka ini naik dari hasil Riskeda tahun 2007 sebesar 8,2\%. Pravelensi stroke terlihat meningkat seiring dengan peningkatan usia responden. Sedangkan menurut Dinas Kesehatan Jawa Tengah tahun 2012, pravelensi stroke hemoragik di Jawa Tengah $0,07 \%$ lebih tinggi dari tahun $2011(0,03 \%)$, dan pravelensi stroke non hemoragik tahun $2012 \quad 0,07 \%$ lebih rendah daripada tahun 2011.

Hingga sekitar $50 \%$ stroke diakibatkan oleh peningkatan tekanan darah. Hipertensi merupakan faktor resiko utama yang dapat dimodifikasi. Insiden stroke meningkat sejalan dengan tingginya tekanan darah, di samping itu tekanan darah yang tetap pada penderita stroke berpengaruh buruk terhadap prognosa jangka panjang, baik terhadap kemungkinan terjadinya stroke ulang atau kematian jangka panjang pasca stroke (Cachofeira dkk., 2009).

Pengelolaan dalam menurunkan tekanan darah pasien Stroke Non Hemoragik pada fase non kritis dapat dilakukan dengan terapi non farmakologis dan terapi farmakologis. Pengelolaan non farmakologis meliputi perubahan gaya hidup, aktivitas fisik, dan terapi relaksasi. Sedangkan terapi farmakologis dapat meliputi pemberian obat antihipertensi.

Slow Stroke Back Massage (SSBM) adalah salah satu terapi relaksasi berupa massage (pijatan) untuk menurunkan tekanan darah. Slow Stroke Back Massage merupakan gerakan sentuhan dan penekanan pada kulit area punggung yang memberikan efek rileksasi pada otot, tendon dan ligament sehingga meningkatkan aktivitas saraf parasimpatis untuk merangsang pengeluaran neurotransmitter asitelkolin. Neurotransmitter asetikolin selanjutnya menghambat aktivitas saraf simpatis sehingga terjadi vasodilatasi sistemik dan penurunan kontraktilitas otot jantung yang bermanifestasi pada penurunan kecepatan denyut jantung, curah jantung serta volume sekuncup yang pada akhirnya menyebabkan penurunan tekanan darah (Retno, 2012).

Berdasarkan penelitian yang dilakukan oleh Retno dan Dian tahun 2011 di Puskesmas Pembantu Blabak Kota Kediri, menunjukkan terdapat pengaruh yang signifikan antara pemberian terapi slow stroke back massage dengan penurunan tekanan darah pada pasien hipertensi.

Dari hasil data yang didapatkan di bangsal syaraf Melati 4 RSUP. Dr. Soeradji Tirtonegoro Klaten pada awal tahun 2016 bulan Januari terdapat 38 pasien yang dirawat dengan penyakit 
stroke. Pada bulan Februari 2016 jumlah pasien Stroke Non Hemoragik yang dirawat di Ruang Melati 4 sebanyak 35 orang. Sedangkan pada bulan Maret 2016 jumlah pasien Stroke Non Hemoragik yang dirawat di Ruang Melati 4 mengalami penurunan menjadi 26 orang, hal ini juga berlangsung juga pada bulan April 2016 dimana jumlah pasien Stroke Non Hemoragik yang dirawat 18 orang (Buku Keluar Masuk Ruang Melati 4 RSUP. Dr. Soeradji Tirtonegoro Klaten, 2016).

Dari laporan studi pendahuluan yang dilakukan penulis selama 2 bulan di Ruang Melati 4 RSUP. Dr. Soeradji Tirtonegoro Klaten pada bulan Mei sampai dengan bulan Juni 2016 didapatkan jumlah Pasien Stroke Non Hemoragik yang dirawat di Ruang Melati 4 RSUP. Dr. Soeradji Klaten sebanyak 32 orang.

Dari pengamatan yang dilakukan oleh peneliti di Ruang Melati 4 RSUP. Dr. Soeradji Tirtonegoro Klaten dalam menurunkan tekanan darah pada pasien Stroke Non Hemoragik berfokus pada penatalaksaan farmakologis dan kurang memperhatikan penatalaksanaan secara non farmakologis seperti terapi Slow Stroke Back Massage. Sehingga penelitiasn ini bertujuan untuk mengetahui karakteristik responden pasien Stroke Non Hemoragik dan mengetahui perubahan tekanan darah pada pasien Stroke Non Hemoragik sebelum dan setelah dilakukan terapi Slow Stroke Back Massage.

\section{METODE PENELITIAN}

Jenis penelitian ini termasuk dalam jenis penelitian quasi eksperiment dengan rancangan One Group PretestPostest Design, rancangan ini tidak ada kelompok pembanding (kontrol) dengan mencakup pengaruh terapi Slow Stroke Back Massage terhadap perubahan tekanan darah pada pasien Stroke Non Hemoragik.

Populasi yang diambil dalam penelitian ini adalah semua pasien Stroke Non Hemoragik di Ruang Melati 4 RSUP. Dr. Soeradji Tirtonegoro Klaten dalam 2 bulan pada tanggal 10 Mei 2016 sampai 25 Juni 2016 dengan jumlah populasi sebanyak 32 orang. Sampel dalam penelitian ini adalah pasien Stroke Non Hemoragik di Ruang Melati 4 RSUP. Dr. Soeradji Tirtonegoro Klaten dalam 2 bulan tanggal 10 Mei 2016 sampai 25 Juni 2016 sesuai dengan kriteria inklusi dan eksklusi. Teknik pengambilan sampel dalam penelitian ini termasuk nonprobability sampling dengan teknik purposive sampling. Purposive Sampling adalah teknik penetapan sampel dengan cara memilih sampel diantara populasi sesuai yang dikehendaki penulis (tujuan/ masalah dalam penelitian), sehingga sampel tersebut dapat mewakili karakteristik populasi yang telah dikenal sebelumnya.

Teknik pengambilan sampel dalam penelitian ini termasuk nonprobability sampling dengan teknik purposive sampling. Purposive Sampling adalah teknik penetapan sampel dengan cara memilih sampel diantara populasi sesuai yang dikehendaki penulis (tujuan/ masalah dalam penelitian), sehingga sampel tersebut dapat mewakili karakteristik populasi yang telah dikenal sebelumnya.

\section{HASIL PENELITIAN}

Penelitian ini dilakukan di Ruang Melati 4 RSUP. Dr. Soeradji Tirtonegoro Klaten pada tanggal 10 Mei 206 sampai 25 Juni 2016 dengan 30 responden yang 
sesuai dengan kriteria inklusi dan eksklusi. Dari 30 responden setuju untuk dilakukan intervensi penelitian dan tidak ada yang menolak, sehingga hasil penelitian dapat memenuhi tujuan yang telah ditentukan.

1. Karakteristik Responden Pasien Stroke Non Hemoragik

a. Karakteristik Responden Menurut Usia

Tabel 1. Distribusi Frekuensi Responden Menurut Usia.

\begin{tabular}{rrrrrr}
\hline & $\mathrm{N}$ & Mean & Min. & Max. & Std. Deviaton \\
\hline Usia & 30 & 62.97 & 46 & 79 & 8.763 \\
\hline
\end{tabular}

Berdasarkan tabel 1, jumlah

keseluruhan responden yang dilakukan terapi Slow Stroke Back Massage (SSBM) adalah 30 responden. Dari jumlah tersebut dapat diketahui dapat diketahui bahwa rata-rata usia responden adalah 63 tahun dengan usia minimal 46 tahun dan usia maksimal 79 tahun.

b. Karakteristik Responden Menurut Jenis Kelamin

Tabel 2. Distribusi Frekuensi Responden Menurut Jenis Kelamin

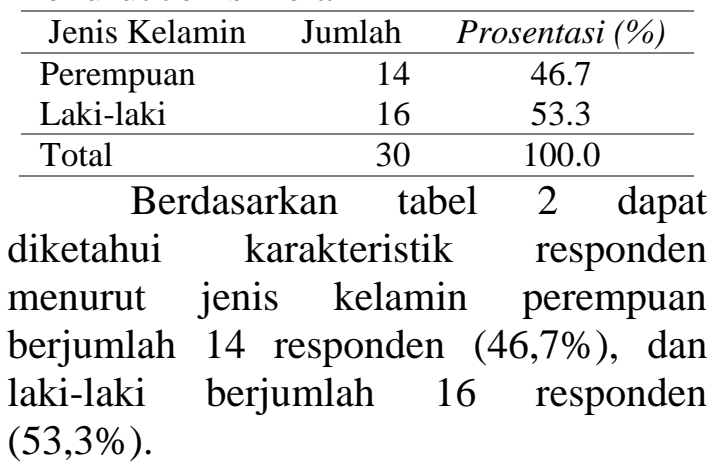

2. Tekanan Darah Responden Sebelum dan Setelah dilakukan Terapi SSBM

Tabel 3. Distribusi Tekanan Darah Responden Sebelum dan Setelah dilakukan Terapi SSBM

\begin{tabular}{|c|c|c|c|c|c|c|}
\hline & & $\mathrm{N}$ & Mean & Min. & Max. & $\begin{array}{r}\text { Std. } \\
\text { Deviaton }\end{array}$ \\
\hline \multirow{2}{*}{$\begin{array}{l}\text { Sebel } \\
\text { um } \\
\text { SSB } \\
\text { M }\end{array}$} & $\begin{array}{l}\text { Sistol } \\
\mathrm{ik}\end{array}$ & 30 & 156.67 & 140 & 200 & 16.259 \\
\hline & $\begin{array}{l}\text { Diast } \\
\text { olik }\end{array}$ & 30 & 83.67 & 70 & 100 & 9.994 \\
\hline \multirow{2}{*}{$\begin{array}{l}\text { Setel } \\
\text { ah } \\
\text { SSB } \\
\mathrm{M} \\
\end{array}$} & $\begin{array}{l}\text { Sistol } \\
\mathrm{ik}\end{array}$ & 30 & 129.67 & 100 & 190 & 20.083 \\
\hline & $\begin{array}{l}\text { Diast } \\
\text { olik }\end{array}$ & 30 & 78.67 & 70 & 100 & 6.814 \\
\hline Valid & 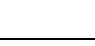 & 30 & & & & \\
\hline
\end{tabular}

responden sebelum dilakukan Terapi SSBM adalah 156,67/83,67 $\mathrm{mmHg}$, dengan nilai tekanan darah minimal 140/70 $\mathrm{mmHg}$, dan nilai tekanan darah maksimal 200/100 mmHg. Sedangkan nilai rata-rata tekanan darah responden setelah dilakukan Terapi SSBM adalah $129,67 / 78,67 \mathrm{mmHg}$, dengan nilai tekanan darah minimal 100/700 $\mathrm{mmHg}$, dan nilai tekanan darah maksimal 190/100 mmHg.

Tabel 4. Perubahan Tekanan Darah

Sebelum dan Sesudah dilakukan Terapi SSBM

\begin{tabular}{|c|c|c|c|}
\hline \multirow{3}{*}{$\begin{array}{l}\text { Tekanan } \\
\text { Darah } \\
\text { Sistolik }\end{array}$} & & Mean & Selisih \\
\hline & Pre SSBM & 156.67 & \multirow[b]{2}{*}{27.00} \\
\hline & Post SSBM & 129.67 & \\
\hline Tekanan & Pre SSM & 83.67 & \multirow[b]{2}{*}{7.00} \\
\hline $\begin{array}{l}\text { Darah } \\
\text { Distolik }\end{array}$ & Post SSBM & 78.67 & \\
\hline
\end{tabular}
diketahui bahwa terdapat selisih nilai mean antara tekanan darah sistolik dan diastolik sebelum dan sesudah dilakukan terapi SSBM sebesar 27.00 dan 7.00. Sehingga penelitian ini menunjukkan terdapat perubahan yang signifikan antara nilai tekanan darah sistolik dan diastolik sebelum dan setelah dilakukannya terapi SSBM pada pasien Stroke Non Hemoragik 
3. Pengaruh Terapi SSBM Terhadap Perubahan Tekanan Darah pada Pasien Stroke Non Hemoragik

Sebelum melakukan uji hipotesis, penulis melakukan uji normalitas. Uji normalitas yang digunakan peneliti adalah Kolmogorov-Smirnov ${ }^{\mathrm{a}}$

Tabel 5. Uji Normalitas KolmogorovSmirnov $^{\mathrm{a}}$

\begin{tabular}{lcccc}
\hline & \multicolumn{3}{c}{ Kolmogorov-Smirnov ${ }^{\mathrm{a}}$} & \multirow{2}{*}{ Keterangan } \\
\cline { 2 - 4 } & Statistic & $\mathrm{df}$ & \multicolumn{1}{c}{ Sig. } & \\
\hline $\begin{array}{l}\text { Sistolik Pre } \\
\text { SSBM }\end{array}$ & .181 & 30 & .014 & Normal \\
\hline $\begin{array}{l}\text { Diastolik } \\
\text { Pre SSBM }\end{array}$ & .243 & 30 & .000 & Tidak normal \\
\hline $\begin{array}{l}\text { Sistolik } \\
\text { Post SSBM }\end{array}$ & .160 & 30 & .048 & Tidak normal \\
\hline $\begin{array}{l}\text { Diatolik } \\
\text { Post SSBM }\end{array}$ & .322 & 30 & .000 & Tidak normal \\
\hline
\end{tabular}

Berdasarkan tabel 5 dapat diketahui nilai sig. tekanan darah sistolik sebelum dilakukan terapi SSBM adalah $0,014(\rho<0,05)$, nilai sig. tekanan darah diastolik sebelum dilakukan terapi SSBM adalah $0,000(\rho<0,05)$, nilai sig. tekanan darah sistolik setelah dilakukan terapi SSBM adalah $0,048(\rho<0,05)$, dan nilai sig. tekanan darah diastolik setelah dilakukan terapi SSBM adalah 0,000 $(\rho<0,05)$. Maka disimpulkan bahwa data tekanan darah sistolik dan diastolik sebelum maupun setelah dilakukan terapi SSBM tidak memiliki distribusi data yang normal.

Sehingga dalam menguji hipotesis, penulis menggunakan maka menggunakan uji nonparametric yaitu Uji Wilcoxon.
Tabel 6. Uji Test Statistics Wilcoxon

Sistolik Setelah Diastolik Setelah SSBM

SSBM - Sistolik - Diastolik Sebelum

Sebelum SSBM SSBM

\begin{tabular}{lcc}
\hline $\mathrm{Z}$ & $-4.872^{\mathrm{a}}$ & $-2.950^{\mathrm{a}}$ \\
Aysmp.S & .000 & .003 \\
ig. (2- & & \\
tailed) & & \\
\hline
\end{tabular}

Berdasarkan dari tabel 6 dapat diketahui bahwa nilai sig. tekanan darah sistolik sebelum dan sesudah dilakukan Terapi SSBM adalah 0,000 $(<0,05)$ dan nilai sig. tekanan darah diastolik sebelum dan sesudah dilakukan Terapi SSBM $0,003(<0,05)$, sehingga dapat disimpulkan bahwa ada terdapat pengaruh terapi Slow Stroke Back Massage terhadap perubahan tekanan darah pada pasien Stroke Non Hemoragik

\section{PEMBAHASAN}

Pembahasan dalam penelitian ini bertujuan untuk menjelaskan tentang hasil penelitian di atas serta membandingkan dengan teori yang ada.

1. Karakteristik Responden Pasien Stroke Non Hemoragik

a. Karakteristik Responden Menurut Usia Dari hasil penelitian yang dilakukan dapat disimpulkan bahwa pada rata-rata usia 63 tahun responden rentan mengalami gangguan sistem persyarafan stroke non hemoragik. Hasil penelitian ini sesuai dengan teori yang menyatakan bahwa insiden stroke meningkat secara eksponensial dengan bertambahnya usia. Pada umumnya risiko terjadinya stroke mulai usia 35 tahun dan akan meningkat dua kali dalam dekade berikutnya. $40 \%$ berumur 65 tahun dan hampir 13\% berumur di bawah 45 tahun. (Lumbantobing, 2001). Hal ini berkaitan dengan proses degenerasi (penuaan) yang terjadi secara alamiah. Pada orang-orang 
dengan lanjut usia, pembuluh darah lebih kaku karena adanya plak.

Penelitian selaras dengan penelitian yang dilakukan Siregar (2002) menunjukkan bahwa umur berpengaruh terhadap kejadian stroke dimana pada kelompok umur $\geq 45$ tahun beresiko terkena stroke 9.451 kali dibandingkan kelompok umur <45 tahun. Dan penelitian yang dilakukan oleh Ritarwan (2002), dari penelitiannya terhadap 45 kasus stroke didapatkan yang mengalami stroke non hemoragik lebih banyak pada rentang umur 45-65 tahun.

b. Karakteristik Responden Menurut Jenis Kelamin

Dari hasil penelitian yang dilakukan dapat diketahui bahwa laki-laki memiliki risiko lebih besar untuk terkena gangguan sistem persyarafan stroke non hemoragik dibandingkan perempuan. Hal ini disebabkan oleh kecenderungan lakilaki memiliki kebiasaan merokok. Merokok dapat meningkatkan risiko terjadinya stroke hampir dua kali lipat. Nikotin dan karbondioksida yang ada pada rokok menyebabkan kelainan pada dinding pembuluh darah penyempitan dan pengerasan arteri di seluruh tubuh (termasuk yang ada di otak dan jantung), yang mana hal ini akan mendorong terjadinya aterosklerosis, mengurangi aliran darah, dan menyebabkan darah mudah menggumpal (Lumbantobing, 2001).

Penelitian ini sejalan dengan penelitian yang dilakukan oleh Utami (2002) mengenai gambaran faktorfaktor resiko yang terdapat pada penderita stroke menunjukkan bahwa jumlah kasus terbanyak jenis kelamin laki-laki 58,4\% dari penelitiannya terhadap 197 pasien Stroke Non Hemoragik. Dan penelitian serupa yang dilakukan oleh Ovina.,dkk (2013) menunjukkan resiko pria terkena stroke 1,25 lebih tinggi daripada wanita.

2. Pengaruh Terapi SSBM Terhadap Perubahan Tekanan Darah pada Pasien Stroke Non Hemoragik

Dari hasil penelitian dapat disimpulkan bahwa terdapat perubahan yang signifikan antara nilai tekanan darah sistolik dan diastolik sebelum dan setelah dilakukannya terapi SSBM pada pasien Stroke Non Hemoragik. Hasil ini dibuktikan dengan uji Wilcoxon yang menunjukkan terdapat pengaruh terapi Slow Stroke Back Massage terhadap perubahan tekanan darah pada pasien Stroke Non Hemoragik. Stroke Non Hemoragik merupakan proses terjadinya iskemia akibat dari adanya emboli dan thrombosis serebral. Penyebab stroke secara umum adalah tekanan darah tinggi atau arteriosklerosis atau kedua-duanya (Muttaqin, 2008). Hipertensi akan menyebabkan tekanan darah atau tekanan pompa jantung menjadi tinggi yang menyebabkan darah mendorong lebih kuat, otak yang merupakan organ mendapatkan suplai darah terbesar dari pembuluh darah akan mendapatkan efek negatif dari hal ini. Perdossi, (2007) menyatakan perbaikan sempurna pada stroke iskemik dipermudah oleh adanya penurunan tekanan darah yang cukup ketika edema otak berkembang sehingga dapat menghasilkan tekanan perfusi serebral yang adekuat Slow Stroke Back Massage merupakan salah satu terapi non farmakologis yang dapat membantu menurunkan tekanan darah sistolik dan diastolik.

Hasil ini sesuai dengan teori yang menyatakan bahwa dengan terapi massage dapat menurunkan tekanan darah sistolik dan diastolik pada pasien yang menderita 
penyakit terminal (Potter \& Perry, 2005). Teori lain juga menyebutkan bahwa terapi (masase) dapat merangsang jaringan otot, menghilangkan toksin, merilekskan persendian, meningkatkan aliran oksigen, menghilangkan ketegangan otot sehingga berdampak terhadap penurunan tekanan darah (Akoso,2009).

Slow Stroke Back Massage dapat meningkatkan relaksasi dengan menurunkan aktivitas saraf simpatis dan meningkatkan aktivitas saraf parasimpatis sehingga terjadi vasodilatasi diameter arteriol (Cassar, 2004). Sistem saraf parasimpatis tersebut melepaskan neurotransmiter asetilkolin untuk menghambat aktifitas saraf simpatis dengan menurunkan kontraktilitas otot jantung, volume sekuncup, vasodilatasi arteriol dan vena kemudian menurunkan tekanan darah (Muttaqin, 2008).

$$
\text { Menurut Akusyati (2009) }
$$

pengaruh terapi Slow Stroke Back Massage adalah dengan memperbaiki peredaran darah yang menyebabkan terjadinya vasodilatasi pembuluh darah di dalam jaringan. Keadaan ini berdampak pada penyaluran zat asam dan bahan makanan ke sel-sel diperbesar dan pembuangan dari zat-zat yang tidak terpakai dapat diperbaiki, sehingga akan timbul proses pertukaran zat yang lebih baik, mengurangi ketegangan pada otototot, meningkatkan relaksasi fisik dan psikologis, menurunkan intensitas nyeri, kecemasan, serta denyut jantung yang berdampak pada penurunan tekanan darah. Tarigan (2009) menyebutkan dengan terapi Slow Stroke Back Massage yang dilakukan secara teratur bisa menurunkan tekanan darah, menurunkan kadar hormon kortisol dan menurunkan kecemasan, sehingga akan berdampak pada perbaikan fungsi tubuh.

Hasil penelitian ini didukung penelitian yang dilakukan oleh Retno \& Dian (2011) yang menunjukkan bahwa tekanan darah pada penderita hipertensi mengalami penurunan signifikan setelah mendapatkan terapi Slow Stroke Back Massage. Penelitian lain yang dilakukan oleh Mohebbi (2014) menunjukkan bahwa setelah intervensi Slow Stroke Back Massage pada pasien hipertensi terjadi penurunan tekanan darah sistolik dan diastolik masing-masing $6.44 \mathrm{mmHg}$ dan $4.77 \mathrm{mmHg}(\rho=0.001)$ pada kelompok intervensi dan 2.31 dan $1.51 \mathrm{mmHg}$ pada kelompok control $(\rho=0.001)$.

\section{KESIMPULAN DAN SARAN}

Penelitian ini memperoleh kesimpulan bahwa: Karateristik rata-rata usia responden Stroke Non Hemoragik di Ruang Melati 4 RSUP. Dr. Soeradji Klaten 63 tahun dan dengan jenis kelamin laki-laki, Nilai rata-rata tekanan darah pada responden Stroke Non Hemoragik di Ruang Melati 4 RSUP. Dr. Soeradji Tirtonegoro Klaten sebelum dilakukan terapi Slow Stroke Back Massage adalah $156,67 / 83,67 \mathrm{mmHg}$, sedangkan nilai rata-rata tekanan darah setelah dilakukan terapi Slow Stroke Back Massage adalah 129,67/78,67 $\mathrm{mmHg}$, terdapat pengaruh terapi Slow Stroke Back Massage terhadap perubahan tekanan darah pada pasien Stroke Non Hemoragik di Ruang Melati 4 RSUP. Dr. Soeradji Tirtonegoro Klaten. Hal ini dibuktikan dengan uji Wilcox on nilai signifikansi tekanan darah sistolik sebelum dan sesudah dilakukan Terapi SSBM adalah 0,000 dan nilai signifikansi tekanan darah diastolik sebelum dan sesudah dilakukan Terapi 
SSBM 0,003, yang artinya $\rho<0,05$, maka Ho ditolak, dan Ha diterima.

Disarankan bagi perawat diharapkan dapat digunakan sebagai bahan informasi tentang penatalaksaan non farmakologis untuk menurunkan tekanan darah pada pasien Stroke Non Hemoragik disamping penatalaksanaan terapi farmakologis, bagi rumah sakit dapat digunakan sebagai bahan sosialisasi dalam meningkatkan pelayanan kesehatan khususnya dalam penatalaksanaan non farmakologis pada pasien Stroke Non Hemoragik untuk menurunkan tekanan darah dan bagi peneliti selanjutnya diharapkan dapat melakukan pengembangan penelitian mengenai penatalaksanaan non farmakologis dalam menurunkan tekanan darah pada pasien Stroke Stroke Non Hemoragik dengan melibatkan variabel yang lebih luas.

\section{DAFTAR RUJUKAN}

Akoso, T. (2009). Bebas Stress. Yogyakarta: Kanisius

Berman, A. and Shirlee, J. S. (2009). alih bahasa Pamilih Eko Karyuni, dkk. 2010. Buku Ajar Fundamental Keperawatan Konsep Proses dan Praktik edisi VII Volume 1. Jakarta : EGC

Cachofeira, V. (2009). Inflammation : A Link Between Hypertension and Atherosclerosis.

Current Hypertension Reviews. Diakses dari

http://www.benthamscience.com/ chr/sample/chr-5-/D000511.pdf pada tanggal 30 Juli 2016

Cassar, M. P. (2004). Hand book of clinical massage $\left(2^{\text {nd }} e d\right)$. London: Elsevier

Churchill Livingstone
Dipiro, J. T. et al., (2011).

Pharmacotherapy Handbook. $6^{\text {th }}$ edition. USA : The Mc.Graw Hill Company

Kusyati, E. (2006). Keterampilan Dan Prosedur Laboratorium Keperawatan Dasar. Jakarta: EGC

Lumbantobing, S. M. (2001). Neurogeriatri Ed $1^{\text {th }}$. Jakarta: BP FK-UI

Mohebbi Z, et all. (2014). The Effect of Back Massage on Blood Pressure in the Patients with Primary Hypertension in 2012-2013: A Randomized Clinical Trial. Diakses dari http:// ijcbnm.sums.ac.ir pada tanggal 31 Juli 2016

Muttaqin, A. (2008). Buku Ajar Asuhan Keperawatan Klien dengan Gangguan Sistem Persyarafan. Jakarta : EGC

Ovina, Y. dkk., (2013). Hubungan Pola Makan, Olah Raga, dan Merokok Terhadap Pravelensi Penyakit Stroke Non Hemoragik. Jurnal : Fakultas Kedokteran dan Ilmu Kesehatan Universitas Jambi

Palmer, A. (2007). Tekanan Darah Tinggi. Jakarta : Erlangga

Perdossi. (2007). Guidline Stroke. Diakses dari

http://clnicalupdates2010.File.wor dpress.com pada tanggal 27 Februari 2016

Potter, P. A. dan Perry, A. G. (2005). Buku Ajar Fundamental Keperawatan Edisi 4 : Konsep, Proses, dan Praktik. Jakarta : EGC

Retno, A. W. dan Dian, P. (2011) Tindakan Slow Stroke Back Massage Dalam Menurunkan Tekanan Darah Pada Penderita 
Hipertensi. Jurnal : STIKES RS Baptis Kediri

Riset Kesehatan Dasar. (2013). Jakarta :

Badan Litbangkes, Depkes RI

Ritarwan, K. (2002). Pengaruh Suhu Tubuh Terhadap Outcome Penderita Stroke yang dirawat di RSUP H. Adam Malik Medan. FK USU: Bagian Ilmu Penyakit Saraf Siregar,F. (2002). Determinan Kejadian Stroke Pada Penderita Rawap Inap RSUP. Haji Adam Malik Medan. Junal Kesehatan Masyarakat: USU. Diakses dari http://www.repository.usu.ac.id/bi tstream/15316/1/ikmjun2005\%20\%281\%29.pdf pada tanggal 30 Juli 2016

Tarigan. (2009). Sehat dengan Terapi Pijat. Diakses dari http://www.mediaindonesia.com tanggal 27 Juni 2016

Utami I. M. (2002). Gambaran FaktorFaktor Risiko Yang Terdapat Pada Penderita Stroke Di RSUD Kabupaten Kudus Semarang. Jurnal : FK UNDIP 